\title{
ENGLISH GGD TEACHER'' VOICE IN THE USE OF ICT FOR TEACHING ENGLISH (BARRIERS AND STRATEGIES)
}

\author{
NENI NURKHAMIDAH \\ STKIP Media Nusantara Citra \\ neninurkhamidah@gmail.com
}

\begin{abstract}
Indonesia is an archipelago country with approximately 17.000 islands in one nation. Many cities have been supported with sufficient and appropriate ICT facilities for education but still many schools in rural area are still far from ideal condition. This research aims at finding out the barriers experience by English GGD as teachers that directly deal with this condition in using ICT for teaching English and the strategies they use to face the barriers. By employing qualitative descriptive study, 17 GGD English teachers were involved. Finding showed that infrastructure and facilities are major barriers faced by teachers in implementing ICT on their teaching. To keep using ICT in teaching they take some strategies such as use their own personal ICT tools, prepare material when they find electricity or internet connection, utilize English GGD teacher group to share teaching material, use energy saving application in their computer, and borrow ICT tools from the closest school. Researcher hope that this study can be further used by our government, school, and stakeholder to provide solutions to its obstacles in implementing ICT for English teaching in remote and rural area.
\end{abstract}

Keywords: GGD, English rural area Teacher, ICT in Language Teaching, Barriers, Strategies,

\section{INTRODUCTION}

The use of ICT has been developing rapidly in recent years throughout the world including Indonesia. Azad (2010) points out that the devices or application to assess, gather, manipulate and present the information such as the computer, mobile phones, radio, television, satellite system, etc is ITC. ICT is a kind of digital tools, it belongs to any kinds of technology to get, manipulate, store, exchange, and produce information (Hoque \& Alam, 2010). ICT includes both hardware such as computers, projectors, digital cameras, and software such as Microsoft Word, PowerPoint, etc. (Wang and Woo, 2007). It is not a new thing, technologies such as televisions, tape recorders and video have been used in teaching and learning since the 1960s (Salehi and Salehi: 2012).

In Indonesian research context, Muslem and Juliana (2018) and Al-Munawwarah (2014) finds out that ICT is very useful for teachers teaching English. Budiman (2018) claims that the use brings huge advantages for teachers, students and education development in Indonesia. Moreover, they also believe that the use of ICT as learning tool 
can help teacher to enhance curriculum and relate them to real life practices. Muslem,Yusuf, \& Juliana(2018) find out that English teachers have positive perceptions of the use of ICT in English Language Teaching. ICT makes class more alive conducting discussion. They all also agree that technology is very beneficial for assisting them in teaching English. Moreover Djiwandono (2019) claims that Indonesian teacher have employed technology-based learning media in their English class because the integration of technology and teaching learning English can make learning more meaningful.

The use of ICT at school requires many considerations such as policy, human resources and facilities. Hermawan and Yunita (2018) point out implementation of ICT in education faces a variety of issues and obstacles that must be solved, including policies, curriculum, infrastructure, lack of expertise, gaps of education and teacher quality. Febriana, Nurkamto, Rochsantiningsih, and Muhtia, A. (2018) propose some lack conditions in Indonesian remote school: 1) infrastructure; 2)source of learning; 3) language barrier; 4) parent mindset; 5) inadequacy of teachers; 6) student competence, and 7) student mindset. Myrad research (2015) that conducted a study in rural and remote areas in Papua show that teachers had to teach multiple early grade classrooms because of a lack of teachers, and teachers' academic backgrounds often mismatched their subjects. Maulida and Lo (2013) find out that financial difficulties, limited human resources and government support as the factors cause unprepared and lack of ICT implementation in public school in a small city in Banda Aceh. Kusumo, Kurniawan and Putri, N. I. (2012). The barriers are connection problem, students' difficulties in understanding the material, students' lack of discipline, independency to study knowledge about the use of ICT.

In 2016 Indonesian Ministry of education, culture and higher education launched a pilot program called Guru Garis Depan $(G G D)$. The program aimed at distributing teachers to remote area. The first batch of GGD program sent 798 professional teachers to 28 districts in remote areas. Four provinces were targeted including Aceh, East Nusa Tenggara, Papua and West Papua. Finding a fact that rural schools are inferior compared to urban schools and only a few schools can easily utilize the ICT (Silviyanti and Yusuf, 2015) researcher try to find out the barriers faced by English GGD teachers in the use of ICT in teaching English and the strategies taken by English GGD teachers to solve the barriers. Because the world now is more complicated and competitive, students have to be equipped to survive in the digitalization era. The beliefs and practices of conventional learning have to be shifted with technological based learning where the support from government is very important to achieve this goal. This study can be further used by our government, school, and stakeholder to provide solutions to its obstacles in implementing ICT for English teaching in remote and rural area.

\section{METHOD}

The aim of this study is to find out the barriers experience by English GGD Teachers Integrating ICT for teaching English and the strategies they use to face the barriers. To answer the research questions, researcher employs a qualitative descriptive study. Qualitative produce the descriptive data, such as; utterance or written texts and people behaviour that are observed. The goal of qualitative study is to summarize specific events experienced by individuals or groups (Lambert and Lambert, 2012). This method is relevant with the aim of the research since in the end of the study the researcher tries to 
summarize the experience of English GGD teachers related to the using of ICT in English teaching.

The study involves 17 teachers (T1 - T17) from 48 English GGD teachers batch one that spread in 48 districts in four provinces in Indonesia namely Aceh, East Nusa Tenggara, Papua and West Papua. Among those 17, 11 teachers teach in senior high school and 6 teachers in junior high school. All teachers teach English at school in rural and remote area. As it is explained before that GGD is a program for distributing teacher in that types area. To identify barriers and strategies in the use of ICT in teaching and learning, online interview was conducted by utilizing WhatsApp application.

Four questions are provided. The first question is a leading question asks teachers' perception about the importance of ICT in education. Second question asks if teachers utilizing ICT or not on their teaching and how they use it. The third question asks what barriers the teachers find in integrating ICT for teaching. The last questionnaire asks to the teachers what strategies they used to face the barriers in the use ICT in teaching English. After the data is collected, researcher organised and assembled the information, interpreted and drew conclusion as the result of research.

\section{FINDINGS AND DISCUSSION}

The results of the online interviews toward 17 English GGD teachers are drawn in this following part.

\section{Barriers in the Using ICT in Teaching English}

The interview is started the question "Is ICT important for teacher in English teaching?". The purpose is to explore teachers' perception about the importance of ICT for teaching and learning English. Researcher randomly write teachers' answer on these following excerpts:

Yes, ICT is very important for effective English teaching and learning. Every teacher should use ICT in English teaching. Teaching with ICT can improve students' vocabularies and speaking skill (T3)

Yes, learning with ICT such as computer and projector will engage my students' motivation to learn. They look so happy whenever I teach them with Video (T7)

Yes, I think ICT is important in education especially in learning English. It is more enjoyable to teach and learn with ICT than using textbook. Many activities can be run with ICT for teaching and learning English. (T10)

Yes, ICT is important. ICT helps teachers to find appropriate English material for teaching. All sources of learning material are available in internet where all teachers can download it (T11)

Yes, ICT is important. Learning speaking using ICT like YouTube and video help students to speak naturally. They also learn new vocabularies from video they watched. (T14) 
ICT is very important both for teacher and students. They can learn how to learn English and culture. Because learning language is also learning culture. Video can help learn both (T15)

ICT is very important for English learning. Students can learn anywhere and anytime if their learning is supported by ICT. Learning is not only hold in the classroom, but they can continue the process in virtual room(T16)

All teachers in this research agree that ICT has important role for English teaching. Some of them also underline that both teacher and students can take a huge amount of advantages by utilizing ICT. As mentioned by teachers and researchers that ICT helps teacher to teach vocabulary (Hussain,2018), motivation (Azmi, 2018; Lasaddi ,2014; Sze, Sheung-hoi, and Kevin ,2004) and listening (Amir, Shamaila \& Kang, Muhammad, 2018 ; Blasco, 2009) and speaking (Appel et all, 2014).

Second question tries to find out if the teachers use ICT or not and what skill they stress in the use ICT on their teaching. From 17 teachers involved in this research, 11 teachers use ICT for teaching and the rest 6 teachers do not utilize ICT on their teaching. From 11 teachers using ICT, 5 of them use ICT in teaching listening, 4 teachers use ICT for speaking, and 2 teachers use it for vocabularies development. Some of teachers' excerpt related to ICT use and stressed skill in the use of ICT in teaching can be seen below:

I use ICT in my teaching, but not always. I usually use ICT for teaching listening. I usually download listening material and video from YouTube (T2)

Yes, I use ICT for teaching. I use song for learning listening. I use new English song and ask my students to listen and do many activities based on the given song. (T3)

I realize that ICT is important, but teachers can't use it since no electricity in my school. As a result, teachers in this school never use it. (T9)

I use ICT in teaching speaking. My students learn conversation from the video and role playing based on the video they watched. (T10)

Yes, I use ICT for vocabulary teaching. My students enjoy learning with picture or video I gave them using LCD projector. (T12)

Third questioner is main question in this research. This question asks 17 teachers about the barriers they found by in the use of ICT in teaching. The answer from the teacher can be seen in this excerpt:

The school is located the middle of isolated area. No electricity and internet connection provided. (T1) 
We don't have computer, LCD projector and internet connection in the school. Actually, I can use my own computer and internet, but I have to do a lot of administrative work for school, so I don't have time to prepare the material. (T4)

Our school does not have computer and projector to support me teaching with ICT. (T5)

The school facilities do not support teachers to conduct teaching using ICT. I need LCD projector and computer. But it seems our school principle does not have effort to provide them for teacher. (T8)

It is hard to implement ICT for teaching without internet connection supporting. I have my own computer but no internet connection in school area. (T9)

The school has limit number of ICT tool. We have one LCD projector only. Not all teachers have chance to use the projector when the projector is being used by other teachers. (T10)

The facilities to conduct teaching and learning by using ICT are very minimal. There is no real support from our government. (T13)

Students are very interest in learning with ICT, but no facilities to support teachers using ICT every time i teach them. (T14)

For listening activities, I need audio speaker. But we don't have it now. (T16)

We don't have computer, LCD projector and internet connection in the school. Actually, I can use my own computer and internet, but the electricity is not always available. (T17)

All teachers in this research find barriers in the use of ICT in teaching. All barriers are related to the ICT facilities and infrastructure. Hermawan and Yunita (2018); Febriana, Nurkamto, Rochsantiningsih, and Muhtia, A. (2018); and Hadijah and Shalawati (2017) find out that major barriers in the implementation of ICT in teaching in rural area are facilities and infrastructure. As it is also mentioned by teachers that the school facilities do not support them to use of ICT. No computer, no LCD projector, no speaker, no internet connection and even no electricity in some area. There is no problem with the teachers and the students from their competencies, perception and willingness to use ICT. Even some teachers also state that students' motivation is increase when teacher use video, audio or song on learning English. They enjoy the activities using those tools more than the learning activity using of book. Both teachers and students are ready to use ICT, the problem is the lack of facilities to support them. 


\section{Strategies Used by Teacher to Face the Barriers}

Some barriers are faced by English GGD teacher in utilizing ICT in the classroom. But they do some efforts that make them keep using it for teaching. What actions taken by teachers to utilize ICT on their teaching can be seen these excerpts:

Sometimes I bring small audio speaker to conduct listening activities with my students. (T2)

I use my own computer and internet tethering from my mobile phone to keep teaching using ICT in my English class. (T3)

I share my own computer with students for teaching speaking and vocabularies. They feel enjoy learning with my computer. (T6)

I teach in a junior high school that the building is beside senior high school. I sometimes borrow LCD projector to teach. (T8)

Because no electricity is provided at my area, I prepare teaching material when I go to city. I usually download video for teaching speaking. (T9)

English GGD teachers have WhatsApp group where teachers usually share material in the group. I use some interesting material to teach the students. I use my phone to show students the video. (T12)

Because no electricity in my school, I use energy saving application to make my computer works longer. (T14)

I prepare all teaching materials at home. Luckily my home is supported with electricity and internet connection. (T17)

The result shows that teachers have different strategies to deal with the barriers they face in using ICT in teaching. As it is mentioned in the previous part, all barriers are related to ICT infrastructure and facilities. Six teachers use personal ICT tools for their teaching. The types of tool they usually use is portable computer, mobile phone, WIFI tethering. Second strategy is preparing material at home or in the city. This strategy is taken by 2 teachers. The materials they prepare for teaching are video, recording, audio they download from internet. One teacher makes use of WhatsApp group as media to share teaching material. One teacher borrows ICT facilities from other school to conduct teaching with ICT. One teacher utilizes energy saving ICT in English teaching because electricity is not available 24 hours in certain remote area.

\section{CONCLUSION}

Based on the research on English GGD teachers' barriers and strategy, researcher draw some conclusion. All the respondence involved in this research have positive perception toward ICT use in teaching English. They mention that the use of ICT in teaching English bring benefit for teachers and students. Students' interest and motivation 
increase when they learn using ICT. For teacher, ICT help them to find appropriate material to teach listening, speaking and vocabulary. All The major barriers faced by teachers in remote area in the use ICT are the lack of infrastructure and facilities that support them to use ICT in teaching. Some areas don't have electricity, internet connections, computer, LCD projector, and audio speaker to be use in teaching. Insipite of this lack, teacher take various strategy to keep conducting English teaching with ICT. Some of them use their own personal ICT tools to teach, prepare material when they find electricity or internet connection, utilize English GGD teacher group to share teaching material, use energy saving application in their computer, and borrow ICT tools from the closest school.

Finding the condition in rural area related to the implementation of ICT in education, Indonesian government have to take action to this issue. Not only national, regional government also need to support English GGD teachers with since all of policies come from them. Teachers and students' positive attitude, perception, and competence about ICT in Language teaching learning will be meaningless without government's support. The last, various study about ICT use in rural educational must be conducted since it offers a huge number benefit for teachers, students and institutions.

\section{References}

Al-Munawwarah, S. F. (2014). Teachers' Perceptions on the Use of ICT in Indonesian EFL Learning Context. English Review: Journal of English Education, 3(1), 70-80.

Amir, Shamaila \& Kang, Muhammad. (2018). Research in Use of Information \& Communication Technologies (ICT) For Developing Listening Comprehension Competency in Foreign/Second Languages: A Review of Selected Tools. 10.5281/zenodo.1403040.

Appel, C., Nic Giolla Mhichíl, M., Jager, S., \& Prizel-Kania, A. (2014). SpeakApps 2: Speaking practice in a foreign language through ICT tools. In S. Jager, L. Bradley, E. J. Meima, \& S. Thouësny (Eds), CALL Design: Principles and Practice; Proceedings of the 2014 EUROCALL Conference, Groningen, The Netherlands (pp. 12-17). Dublin: Research-publishing.net. doi:10.14705/rpnet.2014.000187

Azad, R. K. (2010). Information Technology on Distance Learning. In Saxena Jyotsna \& Rai Geeta. (Eds.). Role of ICT and. total quality management in professional education (pp. 98- 109). New. Delhi: APH Publishing Corporation.

Azmi, N. (2017). The benefits of using ICT in the EFL classroom: From perceived utility to potential challenges. Journal of Educational and Social Research, 7(1), 111-118

Blasco, M. (2009). CALL enhanced L2 listening skills- aiming for autoimmunization in a multimedia environment. Indian Journal of Applied Linguistics, 35 (1), 107-120.

Djiwandono, P. I. (2019). How language teachers perceive information and communication technology. Indonesian Journal of Applied Linguistics, 8(3), 607615. 
Febriana, M., Nurkamto, J., Rochsantiningsih, D. and Muhtia, A. (2018) "RETRACTED: Teaching in Rural Indonesian Schools: Teachers' Challenges", International Journal of Language Teaching and Education, 2(2), pp. 87-96

Hadijah, S., \& Shalawati, S. (2017). Investigating Teachers'barriers To ICT (Information Communication Technology) Integration in Teaching English at Senior High Schools in Pekanbaru. Proceedings of ISELT FBS Universitas Negeri Padang, 5, 302-310.

Hermawan, H. D., Deswila, N., \& Yunita, D. N. (2018, July). Implementation of ICT in Education in Indonesia During 2004-2017. In 2018 International Symposium on Educational Technology (ISET) (pp. 108-112). IEEE.

Hoque, S. M. S., \& Alam, S. M. S. 2010. The Role of Information and Communication Technologies (ICTS) in delivering higher education: A case of Bangladesh. CCSENET, International Education Studies, 3(2). 97-106

Hussain, Z. (2018). The Effects of ICT-Based Learning on Students' Vocabulary Mastery in Junior High Schools in Bandung. International Journal of Education, 10(2), 149-156. doi:https://doi.org/10.17509/ije.v10i2.7592

Kusumo, N. S. A. M., Kurniawan, F. B., \& Putri, N. I. (2012, February). Learning obstacle faced by indonesian students. In The Eighth International Conference on eLearning for Knowledge-Based Society.

B. Lassadi (2014) Using ICT to Increase Learners' and Teachers' Motivation, edulearn14 Proceedings, pp. 2329-2335.

Maulida, I. F., \& Lo, J. (2013). E-learning Readiness in Senior High Schools in Banda Aceh, Indonesia. Information Technology and Applications, 7(4), 122-132.

Muslem, A., Yusuf, Y. Q., \& Juliana, R. (2018). Perceptions and Barriers to ICT use among English Teachers in Indonesia. Teaching English with Technology, 18(1), $3-23$.

Myriad Research. (2015). Baseline Study for Rural and Remote Education Initiative for Papuan Provinces. Report of Findings. Retrieved from https://www.unicef.org/indonesia/Baseline_Study_Papua_Rural Remote_Education_Final_Report.pdf.

Salehi, H., \& Salehi, Z. (2012). Integration of ICT in Language Teaching: Challenges and barriers. In Proceedings of the 3rd International Conference on e-Education, $e$ Business, e-Management and e-Learning (IC4E, 2012), IPEDR (Vol. 27, pp. 215219). 
Sze, Sheung-hoi, and Kevin (2004). Motivating students to learn through the use of ICT : a case study. http://sunzi.lib.hku.hk/hkuto/record/B31598705.

Silviyanti, T. M., \& Yusuf, Y. Q. (2015). EFL teachers' perceptions on using ICT in their teaching: To use or to reject? Teaching English with Technology, 15(4), 29-43.

Wang, Q. and Woo, H. L. (2007): Systematic Planning for ICT Integration in Topic Learning. EducationalTechnology \& Society, 10 (1), 148-156. 